\title{
Changes in air tourism to Tunisia in 2009-2018
}

Authors' Contribution:

A Study Design

B Data Collection

C Statistical Analysis

D Data Interpretation

E Manuscript Preparation

F Literature Search

G Funds Collection

\author{
Jan A. Wendt ${ }^{1 \text { ABDEF, }}$, Dariusz Jacek Olszewski-Strzyżowski ABDEF \\ ${ }^{1}$ University of Gdansk, Gdansk, Poland \\ ${ }^{2}$ Gdansk University of Physical Education and Sport, Gdansk, Poland
}

abstract

Background: The subject of this study is an analysis of the changes of tourist air traffic in Tunisia between 2009 and 2018. During this time, Tunisia saw political changes and worldwide-reported coverage of terrorist attacks on tourists (2014-2015). The aim of this study was to attempt to determine the extent to which the Tunisian Revolution and terrorist attacks have had a negative impact on the decline in the tourist traffic, and to assess the rate of return of the tourist traffic and income in this sector to the levels from before the Revolution.

Material and methods:

The main source of statistical data for Tunisian airports are documents List of the busiest airports in Africa and Trafic Mondial / World Traffic, and data collected from individual airports for the relevant years. The main problem in the analysis and correlation was the access to reliable data on the volume of tourist traffic, and in the case of some airports, data presenting the volume of passenger traffic. Data from the Statistical Office of Tunisia were used to identify and analyse changes in revenues.

Results: Data for 2009-2018 clearly show a decrease in the number of all passengers arriving in Tunisia by air travel.

Conclusions: Research suggests that the decline in the number of tourists as a result of political changes and terrorist attacks has been characterised by different dynamics. Political events have a lower impact on the decrease in the number of tourists and have an effect over a longer period. It seems that after a period of a twofold decrease in the number of tourists - firstly, because of the revolution, and secondly, because of attacks after 2016, Tunisia has entered a period of prosperity in tourism, as evidenced by data for 2017-2018. However, after the record-breaking year 2019, the first quarter of 2020 began under the sign of the Coronavirus pandemic, and tourism around the world is facing a period of stagnation.

Key words: Tunisia, revolution, terrorist attacks, tourist traffic, airport.

\section{article details}

Article statistics: Word count: 3,884; Tables: 2; Figures: 1; References: 28

Received: June 2020; Accepted: August 2020; Published: November 2020

Full-text PDF: http://www.balticsportscience.com

Copyright @ Gdansk University of Physical Education and Sport, Poland

Indexation: Celdes, Clarivate Analytics Emerging Sources Citation Index (ESCl), CNKI Scholar (China National Knowledge Infrastructure), CNPIEC, De Gruyter - IBR (International Bibliography of Reviews of Scholarly Literature in the Humanities and Social Sciences), De Gruyter - IBZ (International Bibliography of Periodical Literature in the Humanities and Social Sciences), DOAJ, EBSCO - Central \& Eastern European Academic Source, EBSCO - SPORTDiscus, EBSCO Discovery Service, Google Scholar, Index Copernicus, J-Gate, Naviga (Softweco, Primo Central (ExLibris), ProQuest - Family Health, ProQuest - Health \& Medical Complete, ProQuest - Illustrata: Health Sciences, ProQuest - Nursing \& Allied Health Source, Summon (Serials Solutions/ProQuest, TDOne (TDNet), Ulrich's Periodicals Directory/ulrichsweb, WorldCat (OCLC)

Funding: This research received no specific grant from any funding agency in the public, commercial, or not-for-profit sectors.

Conflict of interests:

Corresponding author:

Open Access License:
Authors have declared that no competing interest exists.

dr hab. DJ Olszewski-Strzyżowski, prof. AWFiS, Gdansk University of Physical Education and Sport, Górskiego 1 Str. 80-336 Gdansk, Poland; e-mail: jacek.olszewski63@gmail.com

This is an open access article distributed under the terms of the Creative Commons Attribution-Non-Commercial-NoDerivatives 4.0 International (https://creativecommons.org/licenses/by-nc-nd/4.0/), which permits use, distribution and reproduction in any medium, provided the original work is properly cited, the use is non-commercial and is otherwise in compliance with the license. 


\section{INTRODUCTION}

Tourism is one of the fastest growing services in the modern world. The number of tourists between 1950 and 2018 increased almost 50 times [1]. In the same period, revenues from tourism grew from 2 billion USD to 1.5 trillion USD [2]. According to UNWTO forecasts, which do not take into account the coronavirus epidemic, the next two decades for tourism will mean a stable development. It means that each year between 2010 and 2030 the number of foreign travels in the world will increase on average by 43 million. Currently, according to UNWTO, tourism accounts for $5 \%$ of the world's GDP and gives employment to every 12 th employee. It is also the main export element for some countries (this group includes both highly developed and developing countries) [3].

Tourism business plays an important role in many countries, and in several countries, including Tunisia, it is one of the most important sectors of the state economy [4]. It is not surprising that the phenomenon of tourism attracts the attention of governments, local governments, entrepreneurs and numerous researchers of this multi-faceted phenomenon, which is one of the most profitable sectors of the economy and tourist income [5-10].

From a scientific point of view, it is interesting to study the impact of terrorist attacks on the volume of tourism in a country undergoing political transformation. Tunisia next to Egypt is one of the few countries of North Africa, on the example of which, on the one hand, one can indicate changes (decrease) in tourist traffic caused by the political changes in the "Arab Spring" (in the case of Tunisia, the "Jasmine Revolution"), having a permanent character; on the other hand - changes in tourism caused by terrorist attacks that affect tourism in a much shorter time than political problems.

The study analyses changes in the volume of air travel in Tunisia during the political changes called the "Jasmine Revolution" and after the terrorist attacks on tourists that took place in the country in 2014-2015 and the first half of 2016. The purpose is to assess the extent to which tourists have returned to this destination three years after the last media terrorist attacks which reduced tourist traffic. The aim of this research is to determine the magnitude of the negative impact of political riots and terrorist attacks on the decrease in the volume of tourist traffic and the degree of its rebirth in subsequent years, measured by changes in tourist air traffic in the country. Many papers have been published showing the impact of terrorist attacks, followed by obvious reduction in tourism. The implementation of this goal has application significance. It allows shaping the marketing strategy and can be a factor affecting decision making in the field of investment in the development of tourist infrastructure.

The answer to the following two questions seems to be interesting in research and cognitive terms. The first question is: Which of the events: the Jasmine Revolution or the terrorist attacks caused a greater decline in the tourist movement in Tunisia? The second research question concerns the sustainability of the downward trend in tourist traffic, caused by political changes or terrorist attacks in the country. Moreover, it is interesting to note the response to the pace and size of tourists' return from events that have a negative impact on tourist traffic, which can be assessed a few years after the events threatening tourist traffic.

The Revolution in Tunisia has had a significant impact on tourists' safety. Its lack was immediately reflected in the decline in tourist air traffic in the country. A similar case was with the terrorist attacks, which were followed by an immediate decrease in the number of tourists visiting Tunisia. The country was chosen for the analysis of changes in air traffic volumes, because of its natural and anthropogenic qualities. Tunisia is one of the main tourist destinations for European citizens. The notion of political events is understood as all events relevant for the analysed country in domestic policy and in the 
case of terrorist acts in foreign policy. Due to the subject of the study, which is air traffic and the aim of the article, which is to indicate the magnitude of the influence of political factors, the analysis omitted detailed descriptions of the transformation processes in individual countries, aggregating them into landmark events for the local political scene. Thanks to the media, they have the greatest influence on shaping the tourist brand of the country, thus influencing the choice of destinations by tourists.

In order to indicate the size of the changes, airports were selected in the main tourist destinations where both the demographic potential of the resort, tourist values and the functions performed by the city indicate its touristic character. The main problem in the analysis and correlation was access to reliable data on the volume of tourist traffic and, in the case of some airports, data presenting the volume of passenger traffic. The main source of statistical data for Tunisian airports are: List of the busiest airports in Africa [11], Traffic Mondial World Traffic [12], and data collected from individual airports for the relevant years. The data of the Tunisian statistical office were used to identify and analyse changes in revenue.

The years of the Jasmine Revolution (2011-2013) are fundamental in order to show the impact of political events on tourism in the studied countries. However, to show all the changes, data for 2010-2019 were analysed. The same analysis period concerns the impact of the 2014-2015 terrorist attacks and the return of tourism after political stabilisation and the cessation (reduction) of the terrorist threat in the country. Furthermore, the study attempts to evaluate the impact of political changes and terrorist acts on the Tunisian economy, which is heavily dependent on tourism.

\section{METHODS AND MATERIAL}

In this work, simple, classical testing methods were used. According to the literature review [13-16], the use of simple, classic statistical methods is justified in the case of the conducted research, but, of course, a more mathematical research approach can also be found. These include methods of statistical analysis of changes in the volume of tourist traffic - analysis of correlation between changes in tourist traffic at selected airports in relation to political events and terrorist attacks in Tunisia. Statistical analysis was also used to estimate changes in tourist traffic. Due to the course of the Revolution in Tunisia, in which the process of political stabilisation took place the fastest among the countries embraced by the Arab Spring, the years 2010-2012 were selected for the analysis of the decline in tourist traffic. For the assessment of the influence of the terrorist attacks in Tunisia, the changes in tourist traffic in 2015, 2016 and after 2017 have been selected for data availability reasons. When analysing the amount of passenger traffic at Tunisian airports, it should be borne in mind that the changes in the number of passengers show the whole of the changes in passenger traffic, not the tourist traffic itself, and under no circumstances can be equated with the whole of tourist traffic. However, it would appear highly appropriate to request changes in the number of tourists on the basis of changes in the number of passengers at airports, since for European tourists it is air transport that is the main means of travelling to North Africa.

\section{RESULTS}

DETERMINANTS OF TOURISM DEVELOPMENT - POLITICAL FACTORS AND TERRORIST
ATTACKS

The participation of tourists related to the consumption of tourist goods and services is determined by many factors. As Niezgoda and Zmyslony say, these factors must have 
such power of influence as to induce consumers to use the free decision fund for tourism purposes [17].

As we know, the development of tourism is very much dependent on the political stability of a country. Sala notes that tourists going on holiday prefer countries which are politically and economically stable and in which their sense of security will not be affected by anything [18]. Olszewski-Strzyżowski believes that the events which have been intensifying in recent years, such as: terrorism, epidemics and armed conflicts, political instability of some countries, may seriously reduce the demand for certain values, places (destinations) and tourist and recreational services [19]. Similarly, Meyer points out that meeting the need for security is often a condition for deciding on a given holiday destination. This means that the tourist wants to be aware of his personal safety at the place of stay. Therefore, e.g. terrorist attacks on hotels or airplanes affect the periodic decrease in tourist demand [20]. The above is also confirmed by other authors, such as Sönmez and Graefe, who believe that tourists most often choose the destinations that are perceived as the safest [5]. George argues that tourists must feel safe when visiting a destination and when choosing from various tourist and holiday offers [21]. Likewise, Ferreira and Harmse note that the safety of the destination plays a key role in the decision-making process of a tourist who chooses a place of rest [22]. At the same time, Goodrich points out that the feeling of tourists' insecurity, even in the most attractive destination, influences the negative image of this place in the consciousness of other tourists (negative promotion). Thus, it may harm the local tourist industry [23].

New market trends are also a result of geopolitical changes that have recently taken place in the world. This is especially true for the largest tourism market, Europe. These changes result in globalization of tourism supply and demand, involving new countries and destinations in the international tourism exchange. The changes take place in the sphere of needs, preferences and motivation of current and future tourists. On the other hand, they result from increasing competition of tourist goods and services. The abovementioned changes can be observed particularly in recent years, to be precise, among tourists - consumers from European countries. This has resulted in increasing holiday traffic, especially to North African countries, including Tunisia, until the suspension of air services related to the coronavirus epidemic in March 2020 was announced.

\section{Revolution and POLITICAL CHANGe in 2011-2013}

Political demonstrations and the peaceful change of power were called the Jasmine Revolution in Tunisia. It resulted in the resignation of long-time President Ben Ali and the change of government. The riots started in December 2010 and after a week, the whole country was taken over. The new, transitional government resigned in February 2011 under the influence of protests. In July, the Constitutional Assembly was elected, and a year after the riots started, a new president was elected [24]. The revolution in Tunisia triggered a wave of mass social protests that took place in the first months of 2011 in almost all Arab countries. The weakening of central power in North African countries allowed Islamic parties to radicalise and encouraged the emergence of many terrorist militias operating in these areas. This simple calendar allows us to assume that the data for 2010 , extended by the values for 2009 , almost fully presents the level and changes in tourist traffic, so it is possible to relate their volume of data from subsequent years.

\section{TerRorist atTACKS IN TUNISIA IN 2014-2016}

The political upheaval in Tunisia has been accompanied from the beginning by attacks on political opponents and government forces. As in the whole North African region, terrorist attacks on tourists, among others, have a long history in Tunisia. 
In 2002, an attack on the Tunisian island of Djerba took place on the Al-Ghariba synagogue. 21 people died, including 14 German tourists. Al-Qaeda admitted to the attack. The following years without attacks made Tunisia one of the most popular tourist destinations for Europeans. However, the political riots of the Jasmine Revolution and the successful attempt to democratize politics were not widely accepted in the country. One of the first attacks in which Tunisian soldiers died took place in the Tunisian Mountains in July 2014. However, as in Egypt, the attacks were initially carried out against representatives of the Tunisian government, not tourists.

However, on March 18, 2015, during a failed attempt to attack the Tunisian parliament, two bombers retreated to the Bardo Museum building, where they killed 24 tourists from nine European countries and Colombia. Also in this case, like in Egypt, the Islamic State admitted to the assassination. Tourist offices recorded massive cancellations of trips to Tunisia. Tunisian hotels suffered severe losses due to cancellations. On 26 June 2015, in a terrorist attack on the beach in Sousse, in one of the most popular Tunisian resorts, two masked attackers shot at the hotel tourists lying on the beach. 38 foreigners were killed, including thirty Britons and tourists from Ireland, Germany, Belgium, Portugal and Russia [10]. The perpetrator of the attack underwent terrorist training in Libya, and the responsibility for the attack was again assumed by the Islamic State. Due to these events, tour operators from the United Kingdom and Germany massively cancelled tourist trips to Tunisia.

\section{ANALYSIS OF CHANGES IN PASSENGER AIR AND TOURIST TRAFFIC}

The Jasmine Revolution in Tunisia, as well as the Arab Spring in Egypt [9] was reflected in the number of passengers and tourists at Tunisian airports [10]. Although the data are partly estimated, due to the difference in traffic volumes (as reported by official Tunisian institution), there is a clear decline in air traffic between 2011 (revolution) and 20142015 (threat of terrorism). Data for 2009-2018 clearly show a decline in the number of all passengers, including tourists, at all airports, except the newly opened (2010) Enfidha airport. Even at the capital's airport, the number of passengers recorded a drop of $11 \%$ in 2011, compared to the previous year. The classical tourist airports of Djerba and Monastir recorded a fall of $61 \%$ and $71 \%$ respectively in the same year. Such a large loss of passenger traffic at Monastir airport, in addition to political events, is caused due to the relocation of part of the tourist traffic to Enfidha airport. In the next year since the beginning of the revolution 2012 in Tunis, the number of passengers returned to the level of 2010, but at Monastir and Djerba airports the number of passengers still did not reach the level of two years before (Table 1).

Table. 1 Passenger traffic at selected Tunisian airports in 2009-2018 (in thousands*)

\begin{tabular}{|c|c|c|c|c|c|c|c|c|c|c|}
\hline Airport & 2009 & 2010 & 2011 & 2012 & 2013 & 2014 & 2015 & 2016 & 2017 & 2018 \\
\hline $\begin{array}{l}\text { Carthagena - } \\
\text { Tunisa }\end{array}$ & 4257 & 4500 & 3995 & 5249 & $* 5440$ & 5152 & $* 3500$ & 4928 & 5691 & 6200 \\
\hline $\begin{array}{l}\text { Djerba - } \\
\text { Zarzis }\end{array}$ & 2457 & $* 2580$ & 1781 & 1969 & $* 2040$ & 2004 & $* 1360$ & 1249 & 1354 & *1650 \\
\hline Enfidha & - & 500 & 1300 & 2100 & $* 2180$ & 2226 & *1510 & 798 & $* 900$ & 930 \\
\hline $\begin{array}{l}\text { Monastir- Habib } \\
\text { Bourguiba }\end{array}$ & 3852 & 3462 & 1007 & 1239 & 1166 & 1117 & 511 & 793 & 966 & 1561 \\
\hline Total & 10794 & 11332 & 8229 & 10835 & 11236 & 10843 & 7400 & 8039 & 9034 & 10975 \\
\hline
\end{tabular}

Source: authors' own elaboration based on data retrieved from https://en.wikipedia.org/wiki/List_of_the_busiest_airports_in_Africa\#2016 statistics and http://ins.tn/en/themes/tourisme 
Similarly, air traffic at Tunisian airports has seen a decline in the number of tourist arrivals due to the threat of terrorist attacks in 2014 and 2015, with 4\% (2014) and 32\% (2015) of total passenger traffic. It was only from the following year that the number of passengers in 2016 increased by $8.6 \%$, in 2017 by $12.4 \%$ and in 2018 by $21.5 \%$, which indicates a rapid resurgence of tourist traffic in Tunisia.

The 2011 Revolution had a strong impact on the country's economy, especially on its tourism sector [24]. Still in 2010 Tunisia was visited by about 7 million tourists, and in 2011 , only by 4.8 million, which means a decrease in tourist traffic and income by one third. According to data from the World Travel \& Tourism Council, in 2013-2014 almost $15 \%$ of the Tunisian economy was related to the tourism sector and $7 \%$ of GDP came directly from tourism activities. In 2011 Tunisia was visited by almost 2 million less tourists than in the same period of the previous year. There are as many as $50 \%$ fewer tourists from Europe. In the whole of 2014, compared to 2013, there was a drop of $3.4 \%$, and the number of tourists was 6.07 million, over 800,000 fewer than in 2010, and 200,000 fewer than in 2013. The difficult situation of the tourist economy in Tunisia, where about $10 \%$ of hotel facilities had already been closed down, was aggravated by the terrorist attacks of 2015. A detailed breakdown of tourist traffic in Tunisia between 2010 and 2017 is shown in Figure 1.

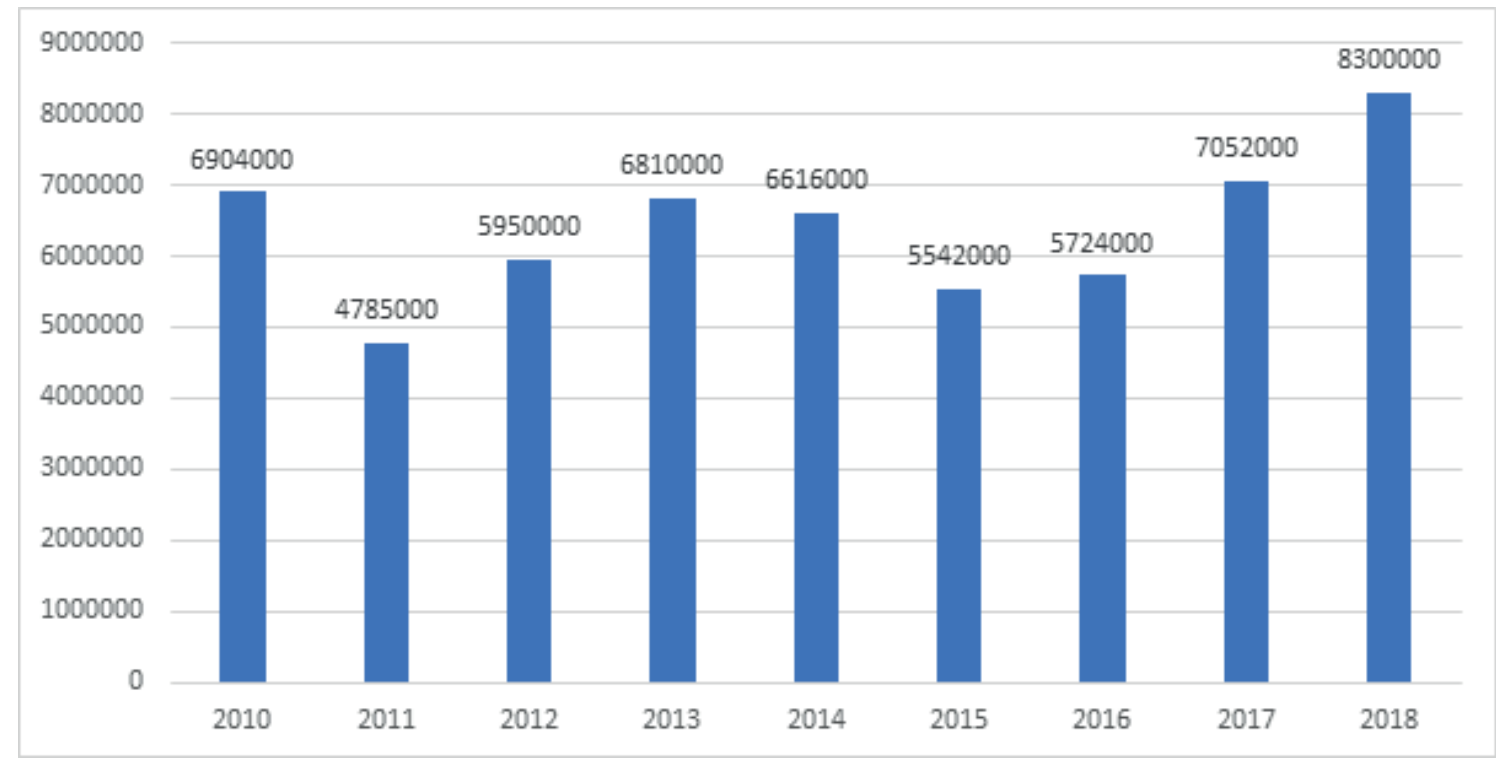

Fig. 1. Tourist traffic in Tunisia 2010-2018

Source: authors' own elaboration based on data retrieved from Users/User/Downloads/Benchmarking Trends Report 2015.pdf and https://eunwto.org/doi/abs/10.5555/unwtotfb0788010020132017201810 and http://tourisme.gov.tn/en/achievements-and-prospects/tourism-in-figures. html

At the same time, changes in inbound tourism in Tunisia between 2014 and 2015, from the most popular European destinations, are presented below (Table 2). Countries from which more than 50 thousand tourists arrived in Tunisia in 2014 were selected to present the decrease in tourist traffic as a result of the threat of a terrorist attack. In total, in 2014, Tunisia was visited by 2.04 million visitors from Europe (47.8\% of all tourists), and in 2015 only 1.06 million (35.2\%), which is a drop of 51.8\% year-on-year [16]. 
Table 2. Changes in inbound tourism in Tunisia between 2014 and 2015, from the most popular European destinations

\begin{tabular}{lccc}
\hline Nationalities & 2014 & 2015 & $\begin{array}{c}\text { Changes 2015/2014 } \\
(\%)\end{array}$ \\
\hline French & 537.8 & 357.3 & -33.6 \\
Britons & 295.1 & 200.8 & -31.9 \\
Germans & 270.4 & 162.2 & -40.0 \\
Russians & 214.3 & 46.3 & -78.4 \\
Italians & 185.1 & 61.3 & -66.9 \\
Belgians & 105.0 & 48.9 & -53.4 \\
Poles & 83.7 & 22.6 & -73.0 \\
Czechs & 65.6 & 32.1 & -51.0 \\
\hline
\end{tabular}

Source: [14]

After the attacks in March at the Bardo Museum in Tunis and in June at Sousse beach, in which many German and British tourists died, passenger traffic at Enfidha and Monastir airports decreased by almost half. In terms of percentage, the number of tourists from Russia, Italy and Poland fell the most. However, given the absolute figures, the biggest drops in the number of tourists / non-residents included travellers from France (180.5 thousand), Russia (168.0 thousand), Germany (108.2 thousand) and the UK (94.3 thousand).The record month in terms of decrease was August 2015, when the total number of passengers fell by over $80 \%$. The attack at the Bardo Museum (March 2015) resulted in a significant drop in the number of tourists from Germany and a significant reduction in the number of tourists who flew to Tunisia in the following months of 2015 compared to the previous year. After March 18, 2015, many bookings were cancelled in Tunisia, which means that in April, 36\% fewer German tourists came to Tunisia than in 2014. The attacks at the end of June had disastrous consequences for the Tunisian tourism sector. In July 2015, compared to July 2014, the number of tourists from Germany decreased by $44 \%$, and from the United Kingdom, from which there were many victims on the beach in Sousse, fell by as much as $84 \%$ [14].

When analysing the presented statistical material, one should remember about the methodological limitations indicated in the introduction and the adopted research assumptions. When analysing the volume of passenger traffic at the airports in Tunisia, it should be remembered that changes in the number of passengers show all changes in passenger traffic, not tourist traffic itself, and in no case can it be equated with all tourist traffic. However, at airports such as Djerba, Enfidha and Monastir, the number of passengers at the airport is significantly related to the volume of tourist traffic and allows making inferences about changes in tourist traffic.

In the analysed period, passenger traffic figures show a clear decrease in the number of tourists in Tunisia. Tunisian airport recorded a drop of $11 \%$ during the revolutionary period and the tourist ports of Djerba and Monastir 61\% and 71\%.

The decrease in the number of tourists was also recorded in 2012. According to the World Travel \& Tourism Council, in 2014, the number of tourists in Tunisia declined by $15 \%$, with the number of tourists from Europe halving. Compared to almost 7 million tourists in 2010, the number of visitors to Tunisia in 2011 decreased by 2 million (Figure 1). Although the following year saw an increase in tourist traffic (by about 1 million) with a tendency to stabilize in 2013-2014, the number of tourists in 2014 was lower by 200,000 compared to the record number of tourists arriving in Tunisia, in 2010.

After the attacks in March in the Bardo Museum in Tunis and in June on the beach in Sousse, in which many German and British tourists died, the monthly passenger traffic 
at Enfidha and Monastir airports decreased by almost half ${ }^{1}$. The record month in terms of decrease was August 2015, when the total number of passengers fell by more than $80 \%$, and also in the following year (2016), this decrease was felt (by 45\%).

The number of tourists in Tunisia in 2011, compared to the previous year, dropped by more than 2 million, and in the next year increased by only one million. It was respectively in 2010 by 6.9 million, in 2011 by 4.8 million, in 2012 by 5.9 million, in 2013 by 6.8 million, in 2014 by 6.6 million, in 2015 by 5.5 million (a decrease again).

In Tunisia, the revolution saw a decline in the number of tourists, but in the following years until 2017, there was a steady, modest but nevertheless increasing number of visitors to the country (to 7.0 million). The terrorist attacks, on the other hand, resulted in an almost immediate, significant decrease in the number of tourists per month, especially from the countries from which the victims of terrorist attacks came from.

\section{CONCLUSIONS}

As can be seen from the above-mentioned data showing changes in the number of passengers at airports and the volume of tourist traffic in Tunisia, the decrease in the number of tourists as a result of political changes and terrorist attacks has been characterized by different dynamics. Political events have a lesser impact on the decline in the number of tourists and have a longer-term effect.

It seems that after a period of twofold decrease in the number of tourists - once due to the revolution, and a second time due to tourist attacks, after 2016 [25]. Tunisia has entered a period of prosperity in tourism, as evidenced by data for 2017-2018, especially if they can recreate the value of their tourism space [26-28]. However, after the record-breaking 2019, for the first seven months alone, more than 5 million tourists visited Tunisia, a $15.6 \%$ increase to the same period in $2018^{2}$ the first quarter of 2020 began under the sign of the coronavirus epidemic, and tourism around the world is facing a period of stagnation.

The analysis confirms the obvious statement that both political instability and terrorist attacks strongly affect the decline in tourism. However, the conducted research and analysis of statistical material allowed pointing to unobvious relations. With the negative impact of the housing of the presented processes, political problems have an impact in the long run, causing a steady decrease in the volume of tourist traffic, in practice terrorist attacks have a much stronger impact (a very fast and significantly larger decrease in the number of tourists), but in a clearly shorter period of time.

However, for the final confirmation of the obtained test results it would be useful to conduct them in a much larger number of cases. In the case of continuing research, it would be useful to analyse the changes in the volume of air traffic in other tourist regions (e.g. Egypt, Indonesia, Turkey).

\section{REFERENCES}

[1] World Tourism Barometer 2018, UNWTO; 2019. https://www.e-unwto.org/doi/abs/10.5555/ unwtotfb0788010020132017201810

[2] Tourism Highlights (2019). UNTWO, 2019 Edition. World Tourism Organization; 2018.

[3] UNWTO World Tourism Barometer and Statistical Annex, January 2019, http://Users/User/Desktop/111014_TT_2030_ global_overview_excerpt.html and https://e-unwto.org/doi/abs/10.5555/unwtotfb0788010020132017201810

[4] Ilieş A, Wendt JA. Geografia turystyczna. Podstawy teorii i zagadnienia aplikacyjne [Tourist geography. Fundamentals of theory and application issues]. Gdańsk, Wydawnictwo AWFiS; 2015. Polish.

${ }^{1}$ Users/User/Downloads/Benchmarking_Trends_Report_2015.pdf

${ }^{2}$ https://aawsat.com/english/home/article/1861441/over-5-million-tourists-visited-tunisia-2019. 
[5] Sönmez SF, Graefe AR. Influence of terrorism risk on foreign tourism decisions. Ann Tourism Res, 1998;25(1):112-144. https://doi.org/10.1016/S0160-7383(97)00072-8

[6] Neumayer E. The impact of violence on tourism - Dynamic cross-national estimation. J Conflict Resol, 2004;48(2): 259-281. https://doi.org/10.1177/0022002703262358

[7] Llorca-Vivero R, Terrorism and international tourism: New evidence. Defense Peace Econom. 2008;19(20):69-188. https://doi.org/10.1080/10242690701453917

[8] Więckowski M, Saarinen J. Tourism transition, changes and the creation of new spaces and places in Central - Eastern Europe. Geographia Polonica. 2019;92(4):369-377. https://doi.org/10.7163/GPol.0154a

[9] Wendt JA. Zmiany w turystycznym transporcie lotniczym Egiptu w latach 2005-2014 [Changes in the tourist air transport of Egypt in 2005-2014]. Prace KGP PTG. 2016;4(30):92-101. Polish.

[10] Wendt JA. Comparison of the impact of the Arab Spring and terrorist attacks on the decline in tourism in Egypt and Tunisia (2010-2015). GeoJournal of Tourism and Geosites. 2019;27(4):1367-1376. https://doi.org/10.30892/ gtg.27421-440

[11] List of the busiest airports in Africa. https://en.wikipedia.org/wiki/List_of_the_busiest_airports_in_Africa\#2016_ statistics

[12] Trafic Mondial World Traffic, 2017, https://haminfo-terminal.com/assets/child/layout/WorldwideAirTraffic2017.pdf $\square$

[13] Poirier RA. Tourism and development in Tunisia. Ann Tourism Res. 1995;22(1):157-171. https://doi.org/10.1016/01607383(94)00053-U

[14] Widz M, Brzezińska-Wójcik T. Dynamika i cechy międzynarodowego ruchu turystycznego w Tunezji w latach 19602015 [Dynamics and features of international tourism in Tunisia in 1960-2015]. Ekonomiczne Problemy Turystyki. 2016;3(35):287-299. Polish. https://doi.org/10.18276/ept.2016.3.35-23

[15] Noureddine S. Tunisian tourism: At the eye of an Arab Spring storm. In: Noureddine S, Almuhrzi H, Alriyami H, Scott N, eds. Tourism in the Arab World. Bristol: Channel View Publications; 2017, 145-160. https://doi. org/10.21832/9781845416157-011

[16] Widz M, Brzezińska-Wójcik T. Assesment of the overtourism phenomena risk in Tunisia in relation to the Tourism Area Life Cycle Concept. Sustainability. 2020;12(5):1-13. https://doi.org/10.3390/su12052004

[17] Niezgoda A, Zmyślony P. Popyt turystyczny. Uwarunkowania i perspektywy rozwoju [Tourist demand. Conditions and development prospects]. Poznań: WAE; 2003, 73. Polish.

[18] Sala J. Stabilizacja gospodarczo-polityczna a turystyka [Economic and political stabilization and tourism]. Zeszyty Naukowe SGH. 2012;35:10. Polish.

[19] Olszewski-Strzyżowski DJ. Najnowsze trendy i zjawiska demograficzne, ekonomiczne i polityczne na świecie i ich konsekwencje dla turystyki w Polsce oraz działań Polskiej Organizacji Turystycznej. Turystyka w Europie w XX wieku [The newest demographic, economic and political trends and phenomena in the world and their consequences for tourism in Poland and the activities of the Polish Tourist Organization. Tourism in Europe in the 21st century]. Studenckie Zeszyty Naukowe. WSTiH w Gdańsku. 2012:286. Polish.

[20] Meyer B. Obsługa ruchu turystycznego [Tourist traffic service]. Warszawa: Wydawnictwo Naukowe PWN; 2006, 34. Polish.

[21] George R. Tourists' perceptions of safety and security while visiting Cape Town. Tourism Management. 2003;24 (3):575. https://doi.org/10.1016/S0261-5177(03)00003-7

[22] Ferreira S, Harmse A. Crime and tourism in South Africa: International tourists' perceptions and risk. South Afr Geograph J. 2000; 82(2): 84. https://doi.org/10.1080/03736245.2000.9713696

[23] Goodrich JN. September 11, 2001 attack on America: A record of the immediate impacts and reactions in the USA travel and tourism industry. Tourism Management. 2002;23:573. https://doi.org/10.1016/S0261-5177(02)00029-8

[24] Becheur M. The Jasmine Revolution and the tourism industry in Tunisia. In: UNLV Theses/Dissertations/Professional Papers/Capstones. Paper 1141. Las Vegas University of Nevada; 2011.

[25] The World Bank; 2015. http://data.worldbank.org/indicator.

[26] Więckowski M. Tourism space: An attempt at a fresh look. Tourism. 2014;24(1):17-24. https://doi.org/10.2478/tour2014-0002

[27] Ilies A, Dehoorne O, Ilies DC. The Cross-Border Territorial System in Romanian-Ukrainian Carpathian Area. Elements, mechanisms and structures generating premises for an integrated cross-border territorial system with tourist function.Carpathian J Environ Sci. 2012;7(1):27-38.

[28] Ilies A, Hurlay PD, Ilies DC, Baias S. Tourist animation a chance for adding value to traditional heritage: Case study in the land Maramures (Romania). Revista de Etnografie si Folclor. 2017;1(1):131-151. 